\title{
Identified plasma proteins related to vascular structure are associated with coarctation of the aorta in children
}

\author{
Siyu Ma, Junqiang Zheng, Yang Xu, Zhaocong Yang, Yu Zhu, Xiaoqi Su and Xuming Mo*
}

\begin{abstract}
Background: Coarctation of the aorta (COA), presenting with local stenosis of the aorta is involved in many cardiovascular processes. However, there has been little research on the mechanism of coarctation of the aorta.

Methods: Altered proteins were identified by isobaric tag for relative and absolute quantitation (iTRAQ) technology in 8 participants, and further analysed by heatmap, Gene Ontology (GO), Kyoto Encyclopedia of Genes and Genomes pathway (KEGG) and Search Tool for the Retrieval of Interacting Gene (STRING). Of these, two vascular structure-related proteins were further validated by using enzyme-linked immunosorbent assay (ELISA) in a new cohort of COA patients.

Results: 39 differentially expressed plasma proteins were first identified in patients with coarctation of the aorta by iTRAQ. Of these, fibulin-1 (FBLN1) and insulin-like growth factor-binding protein complex acid labile subunit (ALS) were considered candidates and further validation also showed that the level of FBLN1 in the CoA group (8.92 \pm $2.36 \mu \mathrm{g} / \mathrm{ml})$ was significantly higher compared with control group $(6.13 \pm 1.94 \mu \mathrm{g} / \mathrm{ml})$, and the level of ALS in CoA children $(348.08 \pm 216.74 \mathrm{ng} / \mathrm{ml})$ was significantly lower than the level in normal children $(619.46 \pm 274.08 \mathrm{ng} / \mathrm{ml})$.

Conclusions: The differentially expressed proteins identified in the plasma from CoA patients indicated that they may play critical roles in COA and that they could potentially be utilized as biomarkers for diagnosis. Altered vascular related proteins were associated with COA. These results provide a foundation for further understanding and studying the aetiology and pathogenesis of coarctation of the aorta.
\end{abstract}

Keywords: Coarctation of the aorta, Plasma proteins, Vascular structure, FBLN1, ALS

\section{Introduction}

Coarctation of the aorta $(\mathrm{CoA})$ is a diffuse arteriopathy, shown as a local stenosis of the aortic lumen on account of medial wall in-folding and thickening of aortic wall tissue [1]. Three out of 1000 live births had isolated CoA with a male to female ratio of $1.5: 1$ [2]. CoA is a common congenital heart disease (CHD), accounting for 5$8 \%$ of CHD patients [3, 4]. In addition, CoA is usually complicated with other developmental abnormalities of

\footnotetext{
* Correspondence: mohsuming15@njmu.edu.cn

Department of Cardiothoracic Surgery, Children's Hospital of Nanjing Medical University, 72 Guangzhou Road, Nanjing 210008, China
}

the heart and blood vessels, such as ventricular septal defect, aortic arch hypoplasia, patent ductus arteriosus and bicuspid aortic valve [1]. Patients with CoA usually clinically present with arterial systolic hypertension that is generally $>20 \mathrm{mmHg}$ higher in the upper extremities than in the lower extremities, because of the different haemodynamics between the two sides of narrowing area [2]. In addition, the reason for the hemodynamic changes caused by aortic coarctation was that CoA was involved in multi-cardiovascular processes.

The influence of CoA in the cardiovascular system not only manifested as differences in the blood pressure of

(c) The Author(s). 2020 Open Access This article is licensed under a Creative Commons Attribution 4.0 International License, which permits use, sharing, adaptation, distribution and reproduction in any medium or format, as long as you give appropriate credit to the original author(s) and the source, provide a link to the Creative Commons licence, and indicate if changes were made. The images or other third party material in this article are included in the article's Creative Commons licence, unless indicated otherwise in a credit line to the material. If material is not included in the article's Creative Commons licence and your intended use is not permitted by statutory regulation or exceeds the permitted use, you will need to obtain permission directly from the copyright holder. To view a copy of this licence, visit http://creativecommons.org/licenses/by/4.0/ The Creative Commons Public Domain Dedication waiver (http://creativecommons.org/publicdomain/zero/1.0/) applies to the data made available in this article, unless otherwise stated in a credit line to the data. 
the upper and lower limbs, but was also nonnegligible, which resulted from haemodynamic changes caused by stenosis. Many studies have shown, that CoA not only causes abnormalities in anatomy, but also causes changes in pathology and physiology [3-6]. Stenosis is usually located distal to the start of the left subclavian artery and proximal to the ductus arteriosus or ligament [4]. High blood pressure at a narrow location proximal to the heart increased the left ventricle (LV) load, altering LV structure and function gradually [5]. In addition, CoA also influenced the aortic arch and led to wider vasculopathy [7], such as aortic rupture or dissection, adolescent hypertension, coronary and cerebral artery diseases $[8,9]$. A study by autopsying 304 unoperated patients with CoA has shown, that $90 \%$ of patients with CoA, who had survived the first two years of life, died by 55 [10]. Therefore, it was of great significance to investigate the aetiology of CoA.

Vascular alteration was considered a vital event in the process of CoA. Physiological and pathological studies may provide a direction for us to study the aetiology of CoA. A study on changes in narrowed aorta has shown that cystic changes characteristically existed in aortic media with elastin fragmenting and collagen deposition increasing [6]. For improving the prognosis of CoA patients, however, most of the research has focused on how to relieve aortic narrowing via surgery [10-13]. Further molecular studies on the vasculature may contribute to the understanding of the aetiology of CoA. Some studies have focused on genetic or proteomic studies to uncover the pathogenesis of CoA. Of these, natriuretic peptide receptor $C$ (NPR-C) was identified as being correlated with CoA by using RNA sequencing in aortic tissue from humans and by validating the results in human aortic endothelial cells [14]. In addition, by analysing aortic tissue, a proteomic/phosphoproteomic study on CoA patients with bicuspid and normal tricuspid aortic valve has shown that the change in proteins related to elastin, oxidative stress and inositol signalling pathways may influence the risk of cardiovascular events [15]. However, this study did not investigate the proteins that may increase the risk of having CoA. However, there is no research on human CoA-related plasma proteins by using the isobaric tag for relative and absolute quantitation (iTRAQ) method, which could more exactly reflect the levels of protein expression [16]. Plasma proteins related to CoA may uncover the possible genetic deficiency and mechanisms of CoA, which have strong clinical significance.

In our study, we identified two differentially expressed proteins (DEPs) related to vascular structure from the plasma of CoA children compared with those in the plasma of normal children by using the iTRAQ method. These differential proteins may be expected to contribute to promote the understanding of the pathogenesis and aetiology of CoA.

\section{Materials and methods \\ Study population and sample preparation}

From January 2012 to December 2017, we enrolled 54 CoA patients treated in the department of cardiothoracic surgery of Children's Hospital of Nanjing Medical University. The Ethics Committee (Institutional Review Board) of the hospital approved this study protocol (201806182-1). The guardians of CoA children have understood and approved the informed consent. Those CoA children were all evaluated by routine clinical assessments, diagnosed by computed tomography angiography and/or preoperative echocardiography and treated by corrective surgery. Additionally, we also recruited 54 age- and gender-matched children from the Han population as controls in the study. The control group was selected from normal children after the physical examination or the CHD screening programme in the hospital. It was confirmed that all controls do not have cardiac diseases by clinical screening or additional echocardiography.

We collected CoA children's blood before they performed surgery. Each blood sample mixed with ethylene diamine tetraacetic acid was harvested in collection tubes and centrifuged at the speed of $1500 \mathrm{~g}$ for $10 \mathrm{~min}$, which ensured blood cells could be separated from the plasma. Then, we collected plasma and divided it into aliquots. Each was stored frozen at $-80^{\circ} \mathrm{C}$ until we carrying out the analysis.

\section{Depletion of high-abundance proteins}

The high abundant proteins in plasma samples collecting from $\mathrm{CoA}$ and normal children were processed to deplete by using the ProteoMiner ${ }^{\mathrm{rm}}$ Protein Enrichment Small-Capacity Kit (Bio-Rad, China).

\section{Enzymatic hydrolysis and desalination}

An equal amount of protein from each sample was used for trypsin digestion. We digested $100 \mu \mathrm{g}$ protein by using trypsin. First, after using tetraethylammonium bromide (TEAB) to dilute proteins five times, trypsin was added into diluted proteins with trypsin and a protein mass ratio of 1:50. The enzyme solution was hatched for enzymolysis overnight at $37^{\circ} \mathrm{C}$. After enzymolysis, peptides were desalinated with a $\mathrm{C} 18$ column and freeze-dried in vacuum.

\section{Isobaric tags for relative and absolute quantitation (iTRAQ) labelling}

The peptides were dissolved with $0.5 \mathrm{~m}$ TEAB and labelled according to the iTRAQ-8 standard kit (SCIEX) instructions. The samples were labelled and mixed. Then, the mixed peptides were graded and separated 
using the Ultimate 3000 HPLC system (Thermo DINOEX, USA). The column was Durashell C18 $(5 \mu \mathrm{m}$, $100 \mathrm{~A}, 4.6 \times 250 \mathrm{~mm})$. The acetonitrile $(\mathrm{ACN})$ concentration gradually increased under alkaline conditions to achieve the separation of the peptide segment, and one tube was collected every minute with a flow rate of $1 \mathrm{ml} /$ min. A total of 42 secondary fractions were collected and combined into 12 fractions, which were desalted and vacuum dried on the Strata-X column.

\section{Analysis by liquid chromatography-mass spectrometry}

Mass spectrometry data were collected using the TripleTOF 5600 plus liquid mass combined system (SCIEX, USA). The sample was dissolved in $2 \%$ acetonitrile $/ 0.1 \%$ methylic acid and analysed by the TripleTOF 5600 plus mass spectrometer coupled to the Eksigent nano LC system (SCIEX, USA). The polypeptide solution was added to the C18 capture column $(5 \mu \mathrm{m}, 100 \mu \mathrm{m} \times 20 \mathrm{~mm})$ at a time gradient of $90 \mathrm{~min}$ with a flow rate of $300 \mathrm{~nL} / \mathrm{min}$ to elute in a C18 analysis column $(3 \mu \mathrm{m}, 75 \mu \mathrm{m} \times 150$ $\mathrm{mm})$. Two mobile phases in gradient elution are buffer A (98 2\% acetonitrile / $0.1 \%$ formic acid $/ \mathrm{H}_{2} \mathrm{O}$ ) and buffer B (2 98\% acetonitrile / 0.1\% formic acid/ $\mathrm{H}_{2} \mathrm{O}$ ). To perform information-dependent acquisition (IDA), the firstorder mass spectra were scanned at $250 \mathrm{~ms}$ ion accumulation time, and the second-order mass spectra of 30 precursor ions were collected at $50 \mathrm{~ms}$. MS1 spectra were collected in the range of $350-1500 \mathrm{~m} / \mathrm{z}$, and MS2 spectra were collected in the range of $100-1500 \mathrm{~m} / \mathrm{z}$. The dynamic elimination time of precursor ions was set as $15 \mathrm{~s}$.

\section{Protein identification and ITRAQ data analysis}

In this experiment, the basic process of proteome identification based on mass spectrometry was adopted. After a series of optimized processing, the MS/MS data were scored for protein identification by comparison with proteins in the database. ProteinPilot ${ }^{\mathrm{mi}}$ V4.5 search engine (Matrix Science, London, UK; version 2.3.0) matched with AB SCIEX TripleTOF 5600 plus was used to identify proteins. The differentially expressed protein was identified and tested for compliance with two criterias: (a) the false discovery rate was less than $1 \%$ (the "decoy database searching" was used to estimate the false discovery rate) and (b) protein confidence was more than 95\% ("unused ProtScore" $\geq 1.3,-\log (1-\%$ confidence/100) was defined as unused ProtScore). The function and the potential linkage of DEPs were exploited by Gene Ontology (GO) enrichment [17], Kyoto Encyclopedia of Genes and Genomes (KEGG) pathway [18], heatmap and Search Tool for the Retrieval of Interacting Gene (STRING) analyses. We used Blast2GO software to obtain GO annotation and abandon blast results when expected value $<0.001$. the $G O$ term was considered when Blast2GO's score was more than 30. KEGG analysis was used to identify the involved pathways. Pathway enrichment was analysed under Fisher's exact test.

\section{Enzyme-linked immunosorbent assay (ELISA)}

Human ELISA kits (CUSABIO, Signalway Antibody) were used for further validation which can detect plasma candidate protein levels in another cohort of 100 subjects (50 CoA children and 50 controls). We performed the validation according to manufacturer's instructions. The validated DEPs met the criterion that (a) proteins expressed differently in CoA and normal children; (b) proteins had underlying pathological or functional significance in CoA; and (c) those proteins have not been previously reported in proteomics study.

\section{Statistical analysis}

Statistical analysis was performed by using GraphPad Prism software (GraphPad Software, San Diego, CA) and SPSS software (SPSS Inc., Chicago, IL, version 17.0). Data are expressed as the mean \pm SEM. The values of $\mathrm{CoA}$ and the control group were compared using the Mann-Whitney $\mathrm{U}$ test. When $p<0.05$, statistical significance was considered.

\section{Results}

\section{Demographic data and proteomic analysis}

Table 1 shows the demographic data of the CoA children and controls in ITRAQ and ELISA studies, and further clinical information was presented in Supplemental Materials Table 1. After iTRAQ labelling and mass spectrometry analysis, 4975 peptides and 539 proteins were identified. The length of peptides was within the allowable range, with an average of 16.26 amino acids. Among those, 39 proteins were identified as statistically significant, which met both $P$ values $<0.05$ by Student's t test and ratios of DEPs $>1.2$ or $<0.83$. Details of all 39 DEPs have been provided in Supplemental Materials Table 2. Of these, fibulin-1 (FBLN1) and insulin-like growth factor-binding protein complex acid labile subunit (IGFALS or ALS) were considered as possible CoAassociated proteins and were validated by ELISA (Table 2).

\section{GO, KEGG, heatmap and STRING analyses}

Figure 1 represents the functional analysis and ratio levels of all DEPs in CoA children compared with controls using the hierarchical clustering algorithm which was based on Euclidean distance. Figure 2 shows the percentage of proteins in each GO term in Homo sapiens. It was found that: a) the GO term enriching the highest percentage of proteins was binding; b) the GO terms only enriching upregulated proteins were 
Table 1 Demographics of study population

\begin{tabular}{|c|c|c|c|c|}
\hline & \multicolumn{2}{|l|}{ iTRAQ } & \multicolumn{2}{|l|}{ ELISA } \\
\hline & $\overline{\mathrm{COA}}$ & Control & $\overline{\mathrm{COA}}$ & Control \\
\hline Number & 4 & 4 & 50 & 50 \\
\hline Gender (M\%) & $2(50 \%)$ & $2(50 \%)$ & $25(50 \%)$ & $25(50 \%)$ \\
\hline Age (months) & $6.97(4,8.1)$ & $5.87(4.5,7.3)$ & $4.63 \pm 2.73$ & $4.08 \pm 1.56$ \\
\hline Weight (kg) & $5.25(5,7)$ & $6.33(5.8,8)$ & $5.24 \pm 0.92$ & $5.18 \pm 1.66$ \\
\hline Length of CoA (mm) & $12.25(7,15)$ & N/A & $10.94 \pm 5.71$ & N/A \\
\hline Diameter of the narrowest $(\mathrm{mm})$ & $2.75(2,4)$ & N/A & $3.40 \pm 1.48$ & $\mathrm{~N} / \mathrm{A}$ \\
\hline \multicolumn{5}{|l|}{ Type } \\
\hline Descending aortic arch (N\%) & & N/A & $11(22 \%)$ & N/A \\
\hline Arch of the aorta (N\%) & $1(25 \%)$ & N/A & $8(16 \%)$ & N/A \\
\hline Isthmus of the aorta (N\%) & $3(75 \%)$ & N/A & $27(54 \%)$ & N/A \\
\hline Arch and isthmus of the aorta (N\%) & & N/A & $4(8 \%)$ & N/A \\
\hline
\end{tabular}

iTRAQ isobaric tags for relative and absolute quantitation, ELISA enzyme-linked immunosorbent assay, CoA Coarctation of the aorta, $M$ male, $\mathrm{kg}$ kilogram, $\mathrm{cm}$ centimeter, $N$ Number, $N / A$ not available

antioxidant activity and structural molecule activity; and c) the GO terms only enriching downregulated proteins were viral reproduction, membrane-enclosed lumen, molecular transducer activity and channel regulator activity. GO analysis indicated that those proteins (Supplemental Materials Table 3) might regulate CoA via influencing the above GO terms. KEGG pathway enrichment exhibited a probable pathway involved in CoA (Fig. 3). STRING analysis was used to predict potential connection between 39 DEPs (Supplemental Materials Figure 1). In addition, we also predicted interaction networks of FBLN1 and ALS (Fig. 4), which could provide more evidence in studying CoA.

\section{ELISA validation of the candidate proteins}

We identified fibulin-1 (FBLN1) and IGFALS (ALS) as candidate proteins and further verified them in the new cohort of CoA children by ELISA $(n=50)$. The reason for choosing the two proteins from 39 DEPs was that they were associated with vascular structure [19], which may correlate to CoA. According to the iTRAQ results, FBLN1 was upregulated in the CoA groups compared to that in the controls, and ALS was downregulated. Further validation by ELISA showed that the level of FBLN1 in the CoA group $(8.92 \pm 2.36 \mu \mathrm{g} / \mathrm{ml})$ was significantly higher than that in the control group $(6.13 \pm 1.94 \mu \mathrm{g} / \mathrm{ml})$, and the level of ALS in CoA children (348.08 \pm 216.74 $\mathrm{ng} / \mathrm{ml}$ ) was significantly lower than the level in normal children $(619.46 \pm 274.08 \mathrm{ng} / \mathrm{ml})$ (Table 3).

\section{Discussion}

Our study was the first to identify the plasma proteins of children with CoA using iTRAQ methods. It was found that 39 proteins were differentially expressed in CoA patients, with 15 upregulated proteins and 24 downregulated proteins. Of these, FBLN1 and ALS, which are related to vascular structure, may be involved in the etiopathogenesis of CoA.

We first chose GO analysis as the break by finding GO terms that only enriched upregulated or downregulated proteins (Supplemental Materials Table 3). It was found that the antioxidant activity and structural molecule activity only enriched upregulated proteins and that viral reproduction, membrane enclosed lumen, molecular transducer activity and channel regulator activity only enriched downregulated proteins. This likely indicated that those GO terms were only activated or inhibited by their enriching proteins in the CoA-related processes. In addition, we further analysed the KEGG pathway of differentially expressed proteins. It was found that most of the DEPs enriched in the four categories of KEGG pathway which were the immunity-related proteins, the coagulation-related proteins, the myocardium-related

Table 2 Candidates of differentially expressed proteins in COA/control Children identified by iTRAQ

\begin{tabular}{llllllll}
\hline Accession & Name & MW (kDa) & Coverage (\%) & Unique peptides & Peptides & CoA/control & KEGG Pathway \\
\hline P2314 & FBLN1 & $77,213.3$ & 61.45 & 40 & 40 & 3.631 & TGF-beta signaling pathway \\
P35858 & ALS & $66,034.1$ & 8.26 & 5 & 5 & 0.240 & ECM-receptor interaction; \\
& & & & & & Hematopoietic cell lineage
\end{tabular}




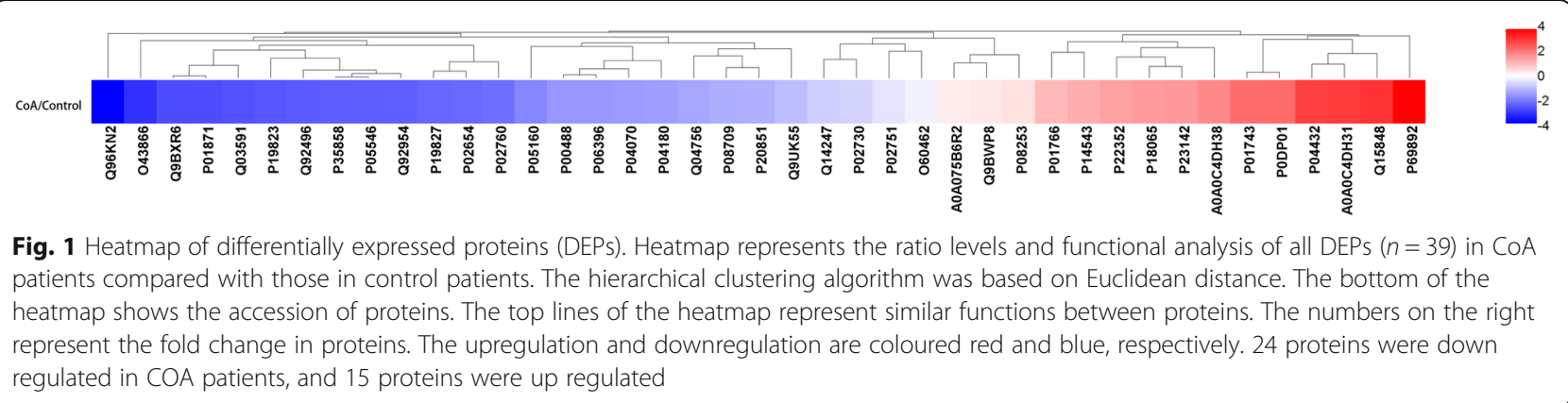

Fig. 1 Heatmap of differentially expressed proteins (DEPs). Heatmap represents the ratio levels and functional analysis of all DEPs ( $n=39)$ in CoA patients compared with those in control patients. The hierarchical clustering algorithm was based on Euclidean distance. The bottom of the heatmap shows the accession of proteins. The top lines of the heatmap represent similar functions between proteins. The numbers on the right represent the fold change in proteins. The upregulation and downregulation are coloured red and blue, respectively. 24 proteins were down regulated in COA patients, and 15 proteins were up regulated

proteins and the vascular structure-related proteins. Considering the succeeding cardiovascular processes after atrial stenosis, the other categories of KEGG pathway except vascular structure-related proteins may be activated or inhibited after vascular structure alteration; for example, the change in the level of myocardium-related proteins was correlated with elevated LV load [20, 21], and vascular structure alteration can influence immunity $[22,23]$ and coagulation [24, 25]. Finally, we focused on the vascular structure-related proteins to track the pathogenesis of CoA.
Vascular structure alteration was considered as the initial event of CoA, according to research on the physiopathology of CoA. Substantial evidence has shown that CoA lesions were mainly located in the arterial wall. It was demonstrated by histological examination that a tissue ridge made up of ductal tissue extended from posterior aortic wall into aortic lumen [26]. Increased carotid intima-media thickness was shown in CoA patients [27]. A study focused on the pathophysiological changes in the narrow artery wall and found that elastin

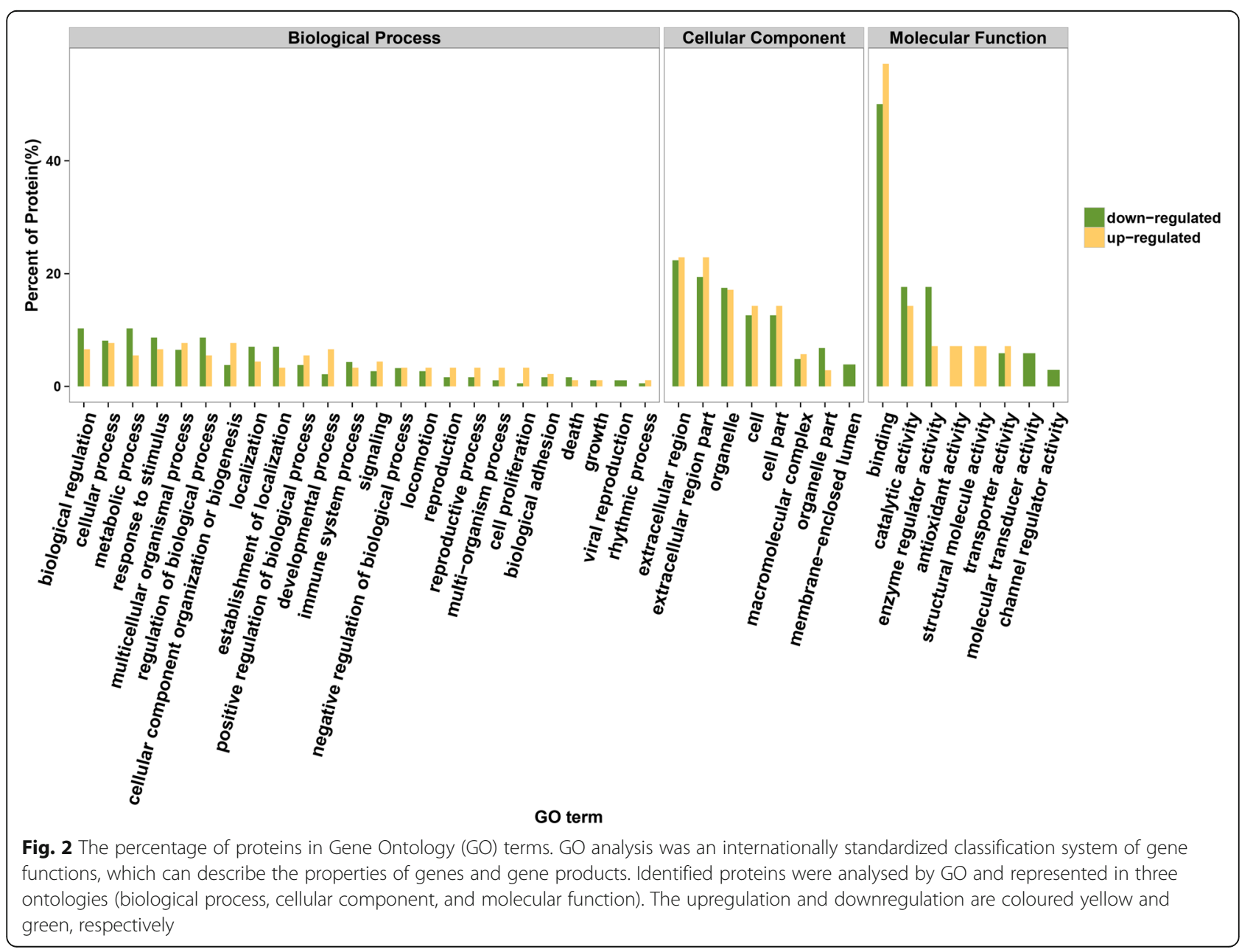




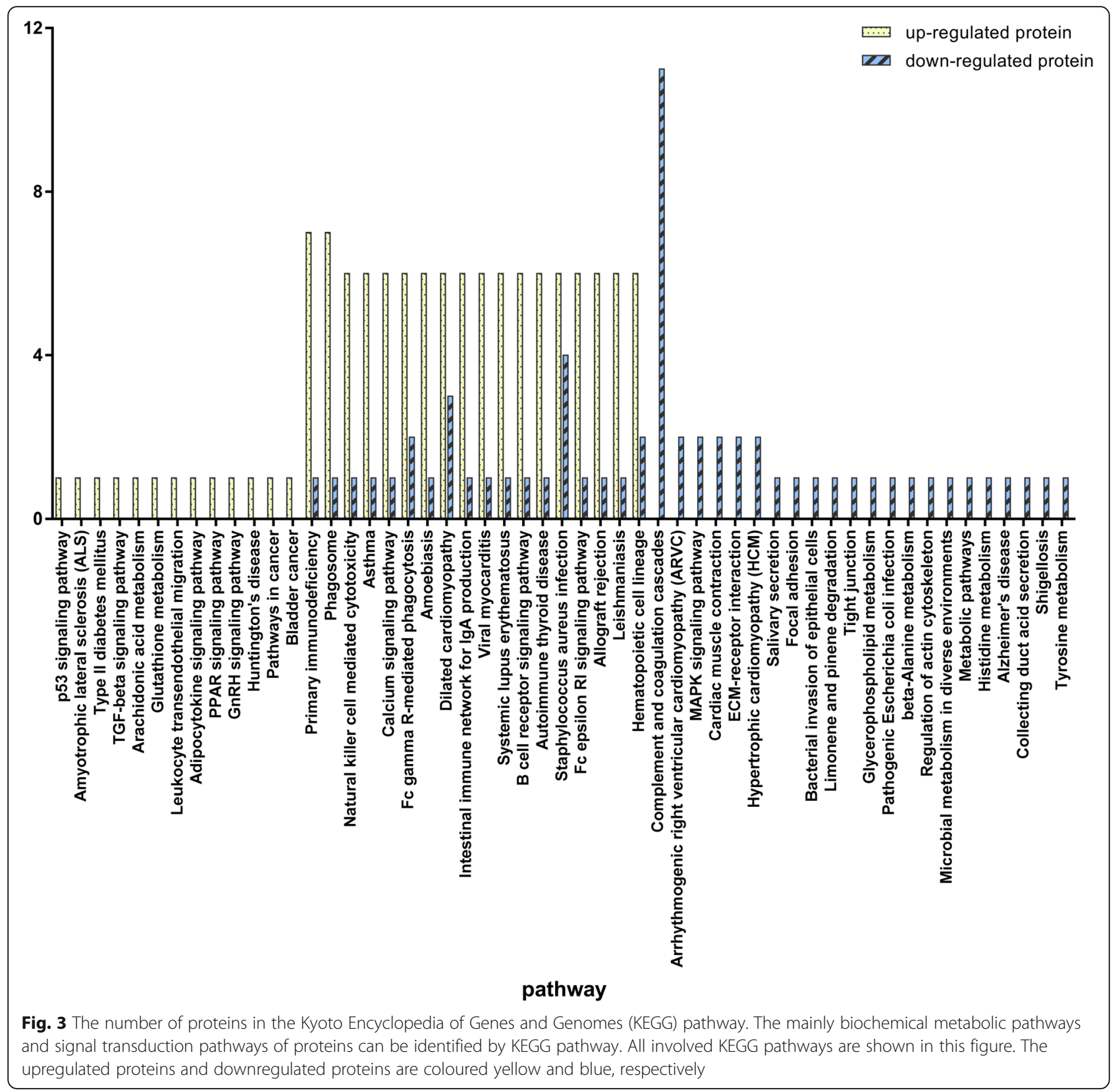

fragmenting and collagen deposition increased in the aortic media [6]. In addition, other studies also considered arterial wall injury to exist in CoA patients with both unrepaired and surgically repaired arterial walls [27, 28]. However, the pathogenesis of $\mathrm{CoA}$ remains unclear. Three potential mechanisms that may illustrate the pathogenesis of CoA were endothelial cell migration defects, abnormal blood flow and excessive deposition of aortic duct tissue in the aortic isthmus [26]. Thus, our study focused on those proteins that may alter vascular structure to increase the risk of CoA. Finally, FBLN1 and ALS were considered candidates related to CoA after further KEGG pathway analysis (Supplemental Materials Table 3).
FBLN1 expressed in the blood vessel walls and cardiac valves is an important extracellular matrix (ECM) protein during cardiac development and can regulate endothelial-to-mesenchymal transition (EMT) [19, 2931]. FBLN1 was identified as a vascular stiffness biomarker in recent years. A study of the relationship between FBLN1 and the arterial wall indicated that the level of serum FBLN1 was statistically related to the aortic augmentation index of peripheral arterial disease. The authors also argued that FBLN1 can influence the transforming growth factor- $\beta$ (TGF- $\beta$ ) pathway to regulate EMT [19], which was verified as the vital role in cardiovascular cells and in many cardiovascular diseases, 

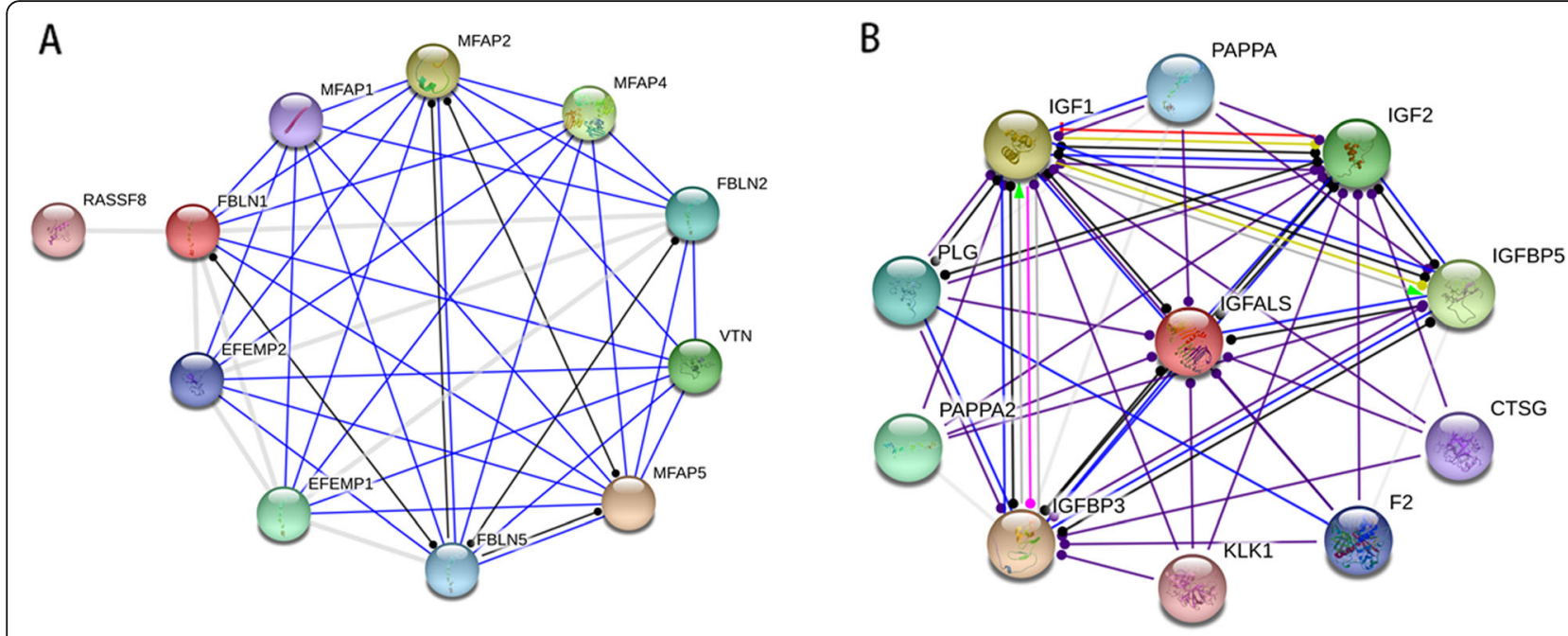

Action Types:
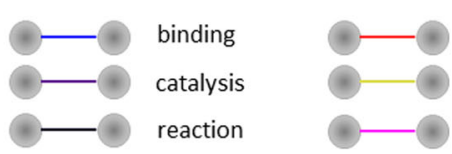

inhibition

Transcriptional regulation

Posttranslational modification

Action Effects:

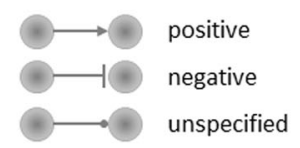

Fig. 4 The interaction networks of FBLN1 and ALS predicted by Search Tool for the Retrieval of Interacting Gene (STRING) analysis. The balls represent predicted related proteins, and the lines between the balls represent interactions among the proteins. Different colours represent different interaction types. a STRING predicted protein-interaction-network of FBLN1; $\mathbf{b}$ STRING predicted protein interaction network of ALS

such as hypertension, cardiac hypertrophy, atherosclerosis and restenosis [32-34]. Thus, we supposed that the level of change in FBLN1 can increase the risk of arterial wall alteration.

ALS is an $85 \mathrm{kDa}$ protein, which was primarily synthesized in the liver and was regulated by growth hormone (GH). ALS can combine with insulin-like growth factorbinding protein (IGFBP) to protect insulin-like growth factor (IGF) from degradation in serum [35, 36]. In contrast, the IGF-IGFBP-ALS complex limits the function of IGF, which must be released from the complex to cross the capillary-endothelial barrier into target tissues [37]. Studies on IGF have shown that it is involved in the migration of human arterial smooth muscle cells (SMCs) [38]; production of nitric oxide in endothelial cells [39, 40]; and some vascular diseases, such as stenotic arteriovenous fistula [41], coronary arteriosclerosis [42], carotid artery intima-media thickening [43] and ischaemic heart disease [44]. In addition, considering that the main effect on IGF release was the proteolysis of IGFBP [36] and that it has been demonstrated in an ALS knockout mouse model that ALS plays a critical role in regulating circulating levels of these proteins $[37,45]$, we hypothesized that ALS mainly plays a role in biological function by influencing the formation of the IGF-IGFBP-ALS complex. As shown in our results, the ALS level was significantly downregulated in the CoA group compared to the ALS level in the control group. Therefore, we hypothesized that lower levels of ALS could act as IGF-regulators to downregulate the level of IGF-1 and are involved in aortic wall reconstruction in CoA.

Table 3 Validation of candidate proteins by ELISA

\begin{tabular}{llll}
\hline & $\operatorname{CoA}(\mathrm{N}=50)$ & Control (N=50) & $\boldsymbol{P}$ value \\
\hline FBLN1 $(\mathrm{\mu g} / \mathrm{ml})$ & $8.92 \pm 2.36$ & $6.13 \pm 1.94$ & $<0.001$ \\
ALS $(\mathrm{ng} / \mathrm{ml})$ & $348.08 \pm 216.74$ & $619.46 \pm 274.08$ & $\mathrm{~N} / \mathrm{A}$ \\
Hospital stays (days) & $30.72 \pm 13.00$ & $\mathrm{~N} / \mathrm{A}$ \\
Time of operation (min) & $231.30 \pm 81.77$ & $\mathrm{~N} / \mathrm{A}$ \\
CPB time (min) & $149.64 \pm 108.07$ & $\mathrm{~N} / \mathrm{A}$ \\
AO time (min) & $56.10 \pm 20.57$ & $\mathrm{~N} / \mathrm{A}$ \\
Supporting time of respiratory $(\mathrm{h})$ & $69.91 \pm 62.60$ & $\mathrm{~N} / \mathrm{A}$
\end{tabular}

ELISA enzyme-linked immunosorbent assay, CoA Coarctation of the aorta, $N$ number, FBLN1 Fibulin-1, ALS Insulin-like growth factor-binding protein complex acid labile subunit, $C P B$ cardiopulmonary bypass, $A O$ aortic occlusion, $N / A$ not available 
However, our study also exhibited some deficiencies. Based on proteomic technology, our results simply presented the plasma level of protein changes, and the mRNA expression needs further validation. In addition, the two proteins were considered as CoA-related candidates by analysing the results of iTRAQ and ELISA and by making conclusions based on the current studies about other vascular diseases; the vital matter, such as TGF- $\beta$ and the IGF-IGFBP-ALS complex, should be detected to critically verify their relation to CoA. Further, deeper research on the function of these proteins should be performed.

\section{Conclusion}

In conclusion, our study was the first to identify differentially expressed proteins by using the iTRAQ method in CoA children, which may explain the underlying mechanisms of CoA. Our results showed that vascular structure alteration was the key event in the initiation and progression of CoA. FBLN1 and ALS are critical proteins that may act as biomarkers for diagnosing $\mathrm{CoA}$ and estimating the conditions of prognosis of $\mathrm{CoA}$ in the clinic. These findings may provide a basis for advancing the understanding of the aetiology and pathogenesis of CoA.

\section{Supplementary information}

Supplementary information accompanies this paper at https://doi.org/10. 1186/s13052-020-00830-7.

\section{Additional file 1}

Additional file 2: Table S1. Clinical information of CoA patients. Additional file 3: Table S2. Differentially expressed proteins in COA/ control Children identified by ITRAQ.

Additional file 4: Table S3. KEGG Pathway of proteins.

\section{Acknowledgments}

None declared.

\section{Authors' contributions}

Mo $X$ designed the research. Ma S, Zheng J and Xu Y performed this research and analysed the relevant data. Yang $Z$ collected samples. Zhu $Y$ and Su X provided the language help. Ma S drafted the manuscript. Mo X critically proofread the manuscript. The authors read and approved the final manuscript.

\section{Funding}

This work was supported by funding from the National Key Research and Development Program of China (2016YFC1101001, 2017YFC1308105); and a Nanjing Medical University School Project (NMUC2018012A).

\section{Availability of data and materials}

Please contact the author for data requests.

\section{Ethics approval and consent to participate}

Not applicable.

\section{Consent for publication}

Consent for publication was obtained from the parents of the child.

\section{Competing interests}

The authors declare that there is no conflict of interest.
Received: 1 November 2019 Accepted: 11 May 2020

Published online: 19 May 2020

\section{References}

1. Dijkema EJ, Leiner T, Grotenhuis HB. Diagnosis, imaging and clinical management of aortic coarctation. Heart. 2017;103(15):1148-55.

2. Aboulhosn J, Child JS. Left ventricular outflow obstruction: subaortic stenosis, bicuspid aortic valve, supravalvar aortic stenosis, and coarctation of the aorta. Circulation. 2006;114(22):2412-22

3. Karaosmanoglu AD, Khawaja RD, Onur MR, Kalra MK CT and MRI of aortic coarctation: pre- and postsurgical findings. AJR Am J Roentgenol. 2015;204(3):W22433 .

4. Baumgartner $H$, Bonhoeffer $P$, De Groot NM, de Haan F, Deanfield JE, Galie $\mathrm{N}$, et al. ESC guidelines for the management of grown-up congenital heart disease (new version 2010). Eur Heart J. 2010:31(23):2915-57.

5. Jashari $H$, Rydberg A, Ibrahimi P, Bajraktari G, Henein MY. Left ventricular response to pressure afterload in children: aortic stenosis and coarctation: a systematic review of the current evidence. Int J Cardiol. 2015;178:203-9.

6. Vukovic I, Lackovic V, Todorivic V, Kanjuh V, llic S. Cytohistologic and immunohistochemical characteristics of the aortic intima and media in coarctation of the aorta of the adult type. Srp Arh Celok Lek. 2004;132 Suppl 1:66-71.

7. Kenny D, Hijazi ZM. Coarctation of the aorta: from fetal life to adulthood. Cardiol J. 2011;18(5):487-95.

8. Lee MGY, Babu-Narayan SV, Kempny A, Uebing A, Montanaro C, Shore DF, et al. Long-term mortality and cardiovascular burden for adult survivors of coarctation of the aorta. Heart. 2019;105(15):1190-6.

9. Cohen M, Fuster V, Steele PM, Driscoll D, McGoon DC. Coarctation of the aorta. Long-term follow-up and prediction of outcome after surgical correction. Circulation. 1989;80(4):840-5.

10. Campbell M. Natural history of coarctation of the aorta. Br Heart J. 1970; 32(5):633-40.

11. Quail MA, Segers P, Steeden JA, Muthurangu V. The aorta after coarctation repair - effects of calibre and curvature on arterial haemodynamics. J Cardiovasc Magn Reson. 2019;21(1):22.

12. Martins JD, Zachariah J, Selamet Tierney ES, Truong U, Morris SA, Kutty S, et al. Impact of treatment modality on vascular function in Coarctation of the aorta: the LOVE - COARCT study. J Am Heart Assoc. 2019;8(7):e011536.

13. Pan M, Ojeda S, Hidalgo F, de Lezo JS, Lostalo A, Mazuelos F, et al. Percutaneous reintervention in patients with aortic coarctation stenting at an early age. Eurolntervention. 2019;15(16):1464-70.

14. LaDisa JF Jr, Tomita-Mitchell A, Stamm K, Bazan K, Mahnke DK, Goetsch MA, et al. Human genotyping and an experimental model reveal NPR-C as a possible contributor to morbidity in coarctation of the aorta. Physiol Genomics. 2019;51(6):177-85

15. Skeffington KL, Bond AR, Abdul-Ghani S, lacobazzi D, Kang SL, Heesom KJ, et al. Bicuspid Aortic Valve Alters Aortic Protein Expression Profile in Neonatal Coarctation Patients. J Clin Med. 2019:8(4).

16. Wiese $\mathrm{S}$, Reidegeld KA, Meyer HE, Warscheid B. Protein labeling by iTRAQ: a new tool for quantitative mass spectrometry in proteome research. Proteomics. 2007;7(3):340-50.

17. Blake JA, Christie KR, Dolan ME, Drabkin HJ, Hill DP, Ni L, et al. Gene Ontology Consortium: going forward. Nucleic Acids Res. 2015;43(Database issue):D1049-56.

18. Kanehisa M, Furumichi M, Tanabe M, Sato Y, Morishima K. KEGG: new perspectives on genomes, pathways, diseases and drugs. Nucleic Acids Res. 2017:45(D1):D353-d361.

19. Harikrishnan K, Cooley MA, Sugi Y, Barth JL, Rasmussen LM, Kern CB, et al. Fibulin-1 suppresses endothelial to mesenchymal transition in the proximal outflow tract. Mech Dev. 2015;136:123-32.

20. Onitsuka K, Ide T, Arai S, Hata Y, Murayama Y, Hosokawa K, et al. Cardiac phasetargeted dynamic load on left ventricle differentially regulates phase-sensitive gene expressions and pathway activation. J Mol Cell Cardiol. 2013;64:30-8.

21. Norris AW, Bahr TM, Scholz TD, Peterson ES, Volk KA, Segar JL. Angiotensin II-induced cardiovascular load regulates cardiac remodeling and related gene expression in late-gestation fetal sheep. Pediatr Res. 2014;75(6):689-96.

22. McEver RP. Selectins: initiators of leucocyte adhesion and signalling at the vascular wall. Cardiovasc Res, 2015:107(3):331-9.

23. Khaddaj Mallat R, John CM, Kendrick DJ, Braun AP. The vascular endothelium: A regulator of arterial tone and interface for the immune system. Crit Rev Clin Lab Sci. 2017;54(7-8):458-70. 
24. Horowitz DL, Moquin RB, Herman CM. Coagulation changes of septic shock in the sub-human primate and their relationship to hemodynamic changes. Ann Surg. 1972;175(3):417-23.

25. Procelewska M, Kolcz J, Januszewska K, Mroczek T, Malec E. Coagulation abnormalities and liver function after hemi-Fontan and Fontan procedures the importance of hemodynamics in the early postoperative period. Eur J Cardiothorac Surg. 2007;31(5):866-72.

26. Nguyen L, Cook SC. Coarctation of the aorta: strategies for improving outcomes. Cardiol Clin. 2015;33(4):521-30 vii.

27. Reiner B, Oberhoffer R, Hacker AL, Ewert P, Muller J. Carotid intima-media thickness in children and adolescents with congenital heart disease. Can J Cardiol. 2018;34(12):1618-23.

28. Tretter JT, Jones TK, McElhinney DB. Aortic Wall injury related to endovascular therapy for aortic Coarctation. Circ Cardiovasc Interv. 2015;8(9):e002840.

29. Cooley MA, Kern CB, Fresco VM, Wessels A, Thompson RP, McQuinn TC, et al. Fibulin-1 is required for morphogenesis of neural crest-derived structures. Dev Biol. 2008;319(2):336-45.

30. Roark EF, Keene DR, Haudenschild CC, Godyna S, Little CD, Argraves WS. The association of human fibulin-1 with elastic fibers: an immunohistological, ultrastructural, and RNA study. J Histochem Cytochem. 1995;43(4):401-11.

31. Miosge N, Gotz W, Sasaki T, Chu ML, Timpl R, Herken R. The extracellular matrix proteins fibulin-1 and fibulin-2 in the early human embryo. Histochem J. 1996;28(2):109-16.

32. Goumans MJ, Ten Dijke P. TGF-beta Signaling in Control of Cardiovascular Function. Cold Spring Harb Perspect Biol. 2018;10(2). https://doi.org/10. 1101/cshperspect.a022210

33. Ruiz-Ortega M, Rodriguez-Vita J, Sanchez-Lopez E, Carvajal G, Egido J. TGFbeta signaling in vascular fibrosis. Cardiovasc Res. 2007;74(2):196-206.

34. Goumans MJ, Liu Z, ten Dijke P. TGF-beta signaling in vascular biology and dysfunction. Cell Res. 2009;19(1):116-27.

35. Garrone S, Radetti G, Sidoti M, Bozzola M, Minuto F, Barreca A. Increased insulin-like growth factor (IGF)-II and IGF/IGF-binding protein ratio in prepubertal constitutionally tall children. J Clin Endocrinol Metab. 2002:87(12):5455-60

36. Lee CY, Rechler MM. Proteolysis of insulin-like growth factor (IGF)-binding protein-3 (IGFBP-3) in 150-kilodalton IGFBP complexes by a cationdependent protease activity in adult rat serum promotes the release of bound IGF-I. Endocrinology. 1996;137(5):2051-8.

37. Arany E, Zabel P, Freeman D, Hill DJ. Elimination of radiolabelled recombinant human insulin-like growth factor binding protein-3 from the circulation, and its distribution amongst organs and tissues in adult male rats. Regul Pept. 1993;48(1-2):133-43.

38. Bornfeldt KE, Raines EW, Nakano T, Graves LM, Krebs EG, Ross R. Insulin-like growth factor-I and platelet-derived growth factor-BB induce directed migration of human arterial smooth muscle cells via signaling pathways that are distinct from those of proliferation. J Clin Invest. 1994;93(3):1266-74.

39. Muniyappa R, Walsh MF, Rangi JS, Zayas RM, Standley PR, Ram JL, et al. Insulin like growth factor 1 increases vascular smooth muscle nitric oxide production. Life Sci. 1997;61(9):925-31.

40. Tsukahara H, Gordienko DV, Tonshoff B, Gelato MC, Goligorsky MS. Direct demonstration of insulin-like growth factor---induced nitric oxide production by endothelial cells. Kidney Int. 1994;45(2):598-604.

41. Stracke S, Konner K, Kostlin I, Schneider M, Herzog R, Jehle PM, et al. Overexpression of IGF-related peptides in stenoses of native arteriovenous fistulas in hemodialysis patients. Growth Hormon IGF Res. 2007;17(4):297-306.

42. Schuler-Luttmann S, Monnig G, Enbergs A, Schulte H, Breithardt G, Assmann G, et al. Insulin-like growth factor-binding protein-3 is associated with the presence and extent of coronary arteriosclerosis. Arterioscler Thromb Vasc Biol. 2000;20(4):E10-5.

43. van den Beld AW, Bots ML, Janssen JA, Pols HA, Lamberts SW, Grobbee DE. Endogenous hormones and carotid atherosclerosis in elderly men. Am J Epidemiol. 2003;157(1):25-31.

44. Juul A, Scheike T, Davidsen M, Gyllenborg J, Jorgensen T. Low serum insulinlike growth factor I is associated with increased risk of ischemic heart disease: a population-based case-control study. Circulation. 2002;106(8):939-44.

45. Boisclair YR, Hurst KR, Ueki I, Tremblay ML, Ooi GT. Regulation and role of the acid-labile subunit of the 150-kilodalton insulin-like growth factor complex in the mouse. Pediatr Nephrol. 2000;14(7):562-6.

\section{Publisher's Note}

Springer Nature remains neutral with regard to jurisdictional claims in published maps and institutional affiliations.

Ready to submit your research? Choose BMC and benefit from:

- fast, convenient online submission

- thorough peer review by experienced researchers in your field

- rapid publication on acceptance

- support for research data, including large and complex data types

- gold Open Access which fosters wider collaboration and increased citations

- maximum visibility for your research: over $100 \mathrm{M}$ website views per year

At $\mathrm{BMC}$, research is always in progress.

Learn more biomedcentral.com/submissions 